\title{
REVIEW
}

\section{Current views on type 2 diabetes}

\author{
Yi Lin and Zhongjie Sun \\ Department of Physiology, College of Medicine, University of Oklahoma Health Sciences Center (OUHSC), BMSB 662A, PO Box 26901, 940 SL Young \\ Boulevard, Oklahoma City, Oklahoma 73104, USA \\ (Correspondence should be addressed to Z Sun; Email: zhongjie-sun@ouhsc.edu)
}

\begin{abstract}
Type 2 diabetes mellitus (T2DM) affects a large population worldwide. T2DM is a complex heterogeneous group of metabolic disorders including hyperglycemia and impaired insulin action and/or insulin secretion. T2DM causes dysfunctions in multiple organs or tissues. Current theories of T2DM include a defect in insulin-mediated glucose uptake in muscle, a dysfunction of the pancreatic $\beta$-cells, a disruption of secretory function of adipocytes, and an impaired insulin action in liver. The etiology of human T2DM is multifactorial, with genetic background and physical inactivity as two critical components.

The pathogenesis of T2DM is not fully understood. Animal models of T2DM have been proved to be useful to study the pathogenesis of, and to find a new therapy for, the disease. Although different animal models share similar characteristics, each mimics a specific aspect of genetic, endocrine, metabolic, and morphologic changes that occur in human T2DM. The purpose of this review is to provide the recent progress and current theories in T2DM and to summarize animal models for studying the pathogenesis of the disease.

Journal of Endocrinology (2010) 204, 1-11
\end{abstract}

\section{Introduction}

It is estimated that diabetes affects about 150 million people worldwide, and this figure is expected to be doubled in the next 20 years (Zimmet et al. 2001). About $90-95 \%$ of all North American cases of diabetes are type 2 diabetes mellitus (T2DM), and about $20 \%$ of the population over the age of 65 has T2DM (Zimmet et al. 2001). About 5-10\% of the total health care budget has been used for T2DM in many countries. T2DM may result in severe complications, including renal failure, blindness, slow healing wounds, and arterial diseases. Here, we review the pathophysiology of T2DM and the major animal models of T2DM.

Diabetes mellitus is often simply considered as diabetes, a syndrome of disordered metabolism with abnormally high blood glucose levels (hyperglycemia) (Tierney 2002). The two most common forms of diabetes are type 1 diabetes (diminished production of insulin) and type 2 diabetes (impaired response to insulin and $\beta$-cell dysfunction). Both lead to hyperglycemia, excessive urine production, compensatory thirst, increased fluid intake, blurred vision, unexplained weight loss, lethargy, and changes in energy metabolism.

T2DM is a complex heterogeneous group of metabolic conditions characterized by increased levels of blood glucose due to impairment in insulin action and/or insulin secretion (Das \& Elbein 2006). Physiologically, the pancreatic $\beta$-cells constantly synthesize insulin, regardless of blood glucose levels. Insulin is stored within vacuoles and released once triggered by an elevation of the blood glucose level. Insulin is the principal hormone that regulates uptake of glucose from the blood into most cells, including skeletal muscle cells and adipocytes. Insulin is also the major signal for conversion of glucose to glycogen for internal storage in liver and skeletal muscle cells. A drop in the blood glucose level results in a decrease in release of insulin from the $\beta$-cells and an increase in release of glucagon from the $\alpha$-cells, which stimulates the conversion of glycogen to glucose. Following an overnight fast, glucose is largely produced by glycogenolysis and gluconeogenesis.

There are three key defects in the onset of hyperglycemia in T2DM: increased hepatic glucose production, diminished insulin secretion, and impaired insulin action (DeFronzo et al. 1992, Stumvoll et al. 2005). Insulin resistance refers to suppressed or delayed responses to insulin. Insulin resistance is generally 'post-receptor', which refers to a problem with the cells that respond to insulin rather than a problem with insulin production. Some rare causes of diabetes include pregnancy, certain medications, or diseases such as maturity onset diabetes in the young (MODY). 


\section{Recent advances in insulin signaling and glucose transport}

\section{Insulin signaling}

Human insulin receptor, a heterodimer, is composed of two extracellular $\alpha$-subunits and two transmembrane $\beta$-subunits (White \& Kahn 1994). The $\boldsymbol{\alpha}$-subunit contains the extracellular ligand-binding domain that regulates intracellular tyrosine kinase activity of $\beta$-subunits (Sciacca et al. 2003, McKern et al. 2006, Ward et al. 2007). Mammalian insulin receptor gene has 22 exons that generate two isoforms by alternative splicing of exon-11, the a-isoform (IRa) retains exon-11 and the b-isoform (IRb) omits exon-11. IRb binds to insulin strongly and predominates in classical insulinsensitive target tissues such as adult liver, muscle, and adipose tissues. By comparison, IRa binds both insulin-like growth factor 2 (IGF2) and insulin with moderate affinity and predominates in fetal tissues, the adult central nervous system, and hematopoietic cells (Louvi et al. 1997). Insulin and IGF receptors reside in the plasma membrane as inactive covalent dimers (Schlessinger 2000). The ligand binding increases flexibility of the activation loop to allow ATP to enter the catalytic site and stabilize the activation loop in the active conformation by autophosphorylation (Hubbard et al. 1994). In higher animals, activated insulin receptor phosphorylates the tyrosine residues in cellular substrates, including insulin receptor substrate (IRS)1, IRS2, IRS3, or IRS4, or other scaffold proteins. Data from transgenic mice suggests that many insulin responses are mediated through IRS -1 or -2 (White 2003).

IRS proteins have a pleckstrin homology $(\mathrm{PH})$ at the $\mathrm{NH}_{2}-$ terminal and phosphotyrosine-binding (PTB) domains, followed by a tail of tyrosine and Ser/Thr phosphorylation sites. The PTB domain binds directly to the phosphorylated NPXY motif in the activated receptors for insulin, IGF1, or interleukin-4 (IL4); the PH domain also facilitates coupling between the IRS proteins and the activated receptors. The tyrosine phosphorylation sites coordinate downstream signaling cascades by binding to the $\mathrm{SH} 2$ domains in common effector proteins - including enzymes (phosphoinositide 3-kinase, the phosphatase SHP2, or the tyrosine kinase fyn) or adapters (GRB2, NCK, CRK, SHB, and others). The classic insulin-like signaling cascades involve the production of $\mathrm{PI}(3,4,5) \mathrm{P}_{3}$ by the phosphatidylinositol 3-kinase (PI3K; Fig. 1). $\mathrm{PI}(3,4,5) \mathrm{P}_{3}$ recruits the Ser/Thr kinases phosphatidylinositol-dependent protein kinase 1 (PDK1) and AKT

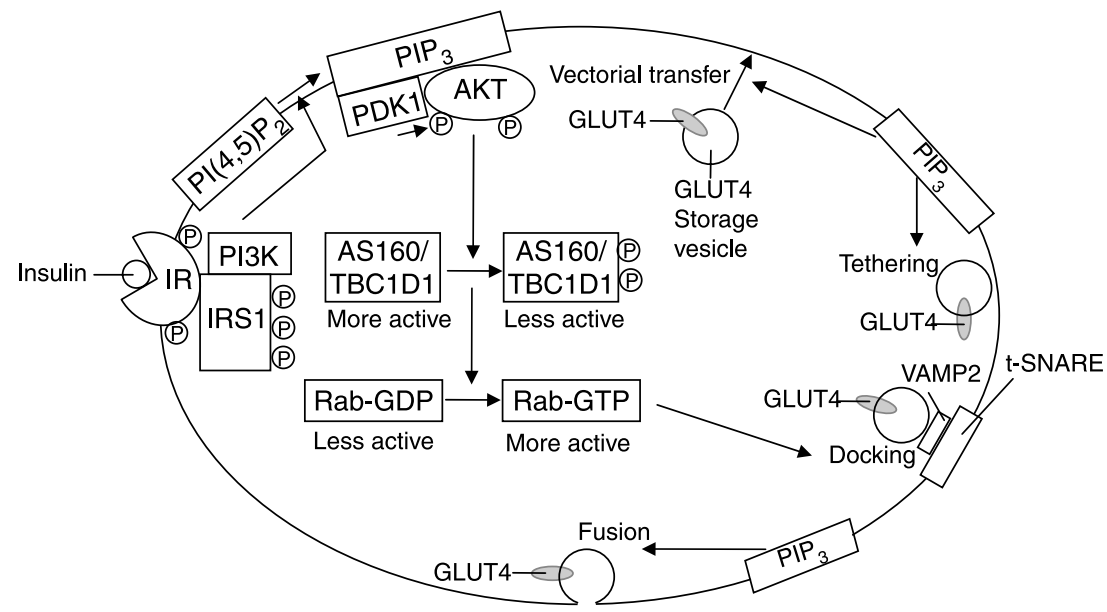

Figure 1 Insulin signaling pathways regulating GLUT4 translocation in mammalian skeletal muscle. Insulin activates tyrosine kinase activity of insulin receptor (IR) by binding with $\alpha$-subunit of IR. Activated IR phosphorylates itself and insulin receptor substrate-1 (IRS1). Phosphorylated IRS1 binds to phosphatidylinositol 3-kinase (PI3-kinase), which is recruited to plasma membrane and converts phosphatidylinositols-4,5-bisphophate $\left(\mathrm{PIP}_{2}\right)$ to phosphatidylinositols-3,4,5-trisphophate $\left(\mathrm{PIP}_{3}\right)$. Increased $\mathrm{PIP}_{3}$ recruits phosphatidylinositoldependent protein kinase-1 (PDK1) and AKT to plasma membrane where AKT is activated by PDK1-mediated phosphorylation. Activated AKT phosphorylates AS160/TBC1D1, which inhibits its Rab GTPase-activating protein (GAP) activity towards particular Rab isoform(s). Inhibition of GAP increases conversion of less active GDP-loaded Rab to more active GTP-loaded Rab. Increased active GTP-loaded Rab then allows GLUT4 storage vesicles to move to, dock, and fuse with plasma membrane. Four stages of GLUT4 translocation have been proposed. Vectorial transfer: GLUT4 vesicles are transported to the cell periphery, possibly along microtubules. Tethering: GLUT4 vesicles are retained near the cell periphery through remodeling actin cytoskeleton. Docking: GLUT4 vesicles bind to plasma membrane via interaction of VAMP2 with target-SNARE complexes. Fusion: irreversible incorporation of GLUT4 vesicles on to plasma membrane is enhanced through action of Munc18c on SNARE proteins. 
to the plasma membrane, where AKT is activated by PDK1-mediated phosphorylation. AKT phosphorylates many proteins, including glycogen synthase kinase $3 \beta$ (GSK3B) in liver, AS160 (GLUT4 translocation), the BADBCL2 heterodimer (antiapoptosis), and forkhead box O transcription factors (regulation of gene expression) (Fig. 1; Taguchi \& White 2008).

Protein phosphatases and phospholipid phosphatases modulate the strength and duration of insulin signals. Depending upon the tissue site, dysregulation of these heterologous signaling mechanisms can progress to glucose intolerance, hyperinsulinemia, dysregulated lipid metabolism, and insulin resistance (White 2003).

\section{Translocation of glucose transporter to plasma membrane}

The transport of glucose into the skeletal muscle cells is the rate-limiting step in whole body glucose metabolism under normoglycemic conditions (Ren et al. 1993). Glucose enters the cell by facilitated diffusion mediated via a group of structurally related glucose transporter proteins (GLUTs). At least 12 GLUTs have been described (Joost et al. 2002). In skeletal muscle and adipose tissue, GLUT1 mediates basal glucose transport, whereas GLUT4 is responsible for insulinmediated glucose uptake (Tordjman et al. 1989).

The stimulation of GLUT4 translocation and glucose uptake by insulin is a complex process. The necessity of the IRS-PI3K-AKT-AS160 axis in insulin-simulated glucose uptake is well documented (Bjornholm \& Zierath 2005). Insulin regulates translocation of GLUT4 in vectorial transfer, vesicle tethering, vesicle docking, and vesicle fusion (Fig. 1; Zaid et al. 2008).

Soluble $N$-ethylmaleimide-sensitive factor attachment protein receptors (SNARE) mediate both docking and fusion events (Foster \& Klip 2000, Kawanishi et al. 2000). Vesicleassociated membrane protein 2 (VAMP2), syntaxin4, and soluble NSF attachment protein 23 are three elements of the SNARE complex involved in docking/fusion of insulinsensitive GLUT4 vesicles with the plasma membrane. The SNARE complex consists of four parallel $\boldsymbol{\alpha}$-helices formed from the coiled-coil segments of SNARE proteins in two opposite membranes (McNew et al. 2000). Prior to docking/ fusion, cis-SNARE complexes exist on vesicles and must be disassembled to allow trans-SNARE complex formation. The disassembly of cis-SNARE complex is driven by the ATPase activity of N-ethylmaleimide-sensitive factor (NSF). NSF recruitment to the cis-SNARE complex requires SNAP (Jahn \& Scheller 2006). NSF is believed to associate with GLUT4 vesicles and cell membranes, but this interaction itself does not impact on the formation of fusion complexes (Mastick \& Falick 1997). The regulation of SNARE complex formation is believed to be exerted via SM (Sec1p/Munc18) (Latham et al. 2006). Among the three mammalian SM genes, Munc18c is involved in GLUT4 trafficking and stabilizing syntaxin in the closed inactive conformation in the basal state. Data have shown that Munc18c dissociates from syntaxin4 upon insulin stimulation (Thurmond et al. 1998, Kanda et al. 2005) and Munc18c may switch to a different binding site on the target-SNARE, thereby allowing VAMP2 and GLUT4 vesicle docking at the plasma membrane (Smithers et al. 2008).

\section{Current understanding of T2DM}

The pathophysiology of T2DM varies with tissues or organs as detailed below. The contribution of each tissue or organ to T2DM is summarized in Fig. 2.

\section{Skeletal muscle}

Since skeletal muscle accounts for $\sim 75 \%$ of whole body insulin-stimulated glucose uptake, defects in this tissue play a major role in the glucose homeostasis in patients with T2DM (Bjornholm \& Zierath 2005). Insulin receptor tyrosine phosphorylation appears to be normal or reduced in nonobese T2DM (Zierath et al. 2000). IRS1 knockout mice demonstrate peripheral insulin resistance and reduced growth; however, these defects are partly compensated by the existence of an IRS1-independent pathway for insulin signal transduction (Araki et al. 1994). This compensatory pathway was shown to be mediated by IRS2 (Sun et al. 1995). IRS2 knockout mice have a progressive development of T2DM, with insulin resistance in skeletal muscle (Lin et al. 2004). Type 2 diabetic subjects have impaired insulin-stimulated tyrosine phosphorylation of IRS1 in skeletal muscle. This is not related to decreased protein expression of IRS1. A similar impairment is observed at the level of PI3K in type 2 diabetic muscle (Zierath et al. 2000). Impaired PI3K activation has been observed in Zucker fatty obese rat (Asano et al. 2007). Whereas IRS1 and PI3K phosphorylation/activation is impaired under in vivo and in vitro insulin stimulation in the skeletal muscle from type 2 diabetic subjects, AKT phosphorylation is impaired only under in vitro conditions (Zierath et al. 2000).

The dysregulation of the insulin receptor or IRS constitutes a common feature of insulin resistance. Mechanisms for this dysregulation might include tumor necrosis factor $\alpha(\mathrm{TNF} \alpha)$-mediated downregulation of mRNA transcription (Hotamisligil et al. 1993, Frittitta et al. 1997, Moller 2000), kinase-mediated serine/threonine phosphorylation (Bandyopadhyay et al. 1997b, De Fea \& Roth 1997, Aguirre et al. 2000, Yu et al. 2002), proteosomemediated degradation (Zhande et al. 2002), and phosphatasemediated dephosphorylation (Worm et al. 1996, Ahmad et al. 1997, Bandyopadhyay et al. 1997a, Elchebly et al. 1999). These signaling abnormalities could result in an impaired glucose transport. Indeed, the insulin-stimulated glucose transport is reduced in the skeletal muscle of type 2 diabetic subjects (Zierath et al. 2000).

Patients with T2DM are characterized by a decreased fat oxidative capacity and high levels of circulating free fatty acids (FFAs; Kelley \& Simoneau 1994, Blaak et al. 2000a,b). 


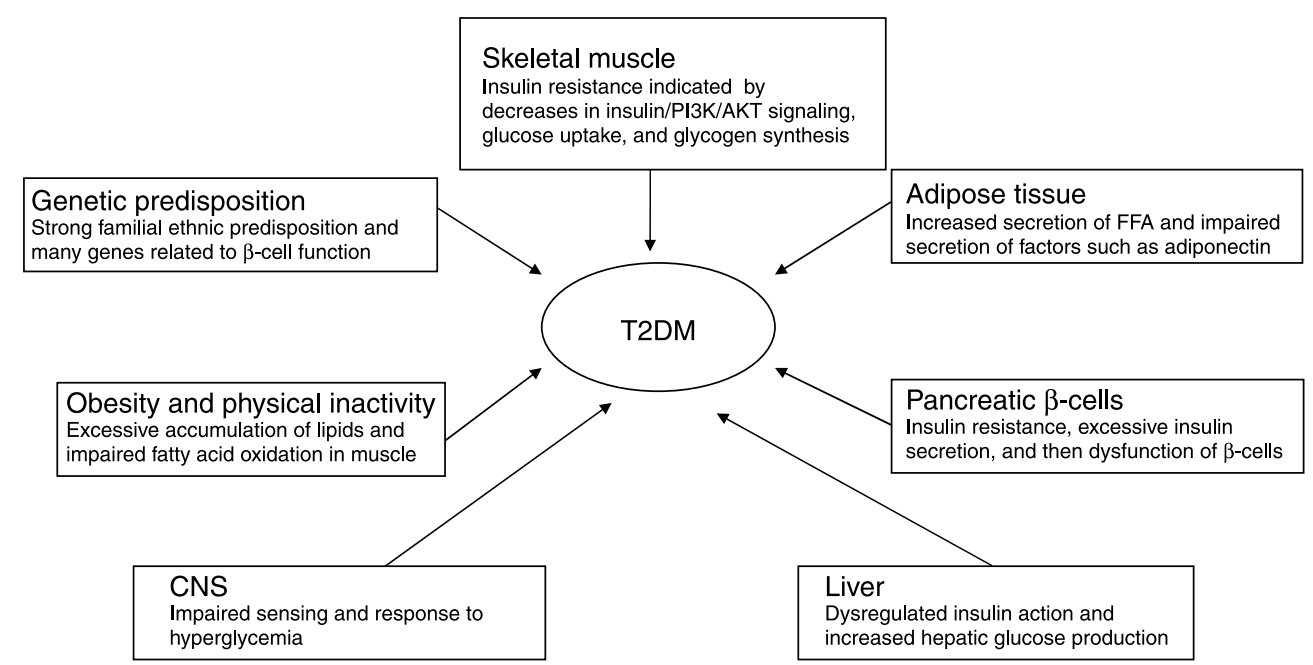

Figure 2 Pathogenesis of T2DM. Current theories on T2DM include a defect in insulin-mediated glucose uptake in skeletal muscle, a disruption of secretory function of adipocytes, a dysfunction of pancreatic $\beta$-cells, impaired sensing and response to hyperglycemia in the CNS, an excessive accumulation of lipids, and impaired fatty acid oxidation due to obesity, physical inactivity, and genetic predisposition.

The latter is known to cause insulin resistance, particularly in skeletal muscle, by reducing insulin-stimulated glucose uptake, most likely via accumulation of lipid inside the muscle cell (Boden 1999, Santomauro et al. 1999). T2DM is associated with impaired metabolic flexibility, i.e. an impaired switching from fatty acid to glucose oxidation in response to insulin (Kelley \& Mandarino 2000). Thus, a reduced fat oxidative capacity and metabolic inflexibility are important components of skeletal muscle insulin resistance. The cause of these derangements in skeletal muscle of type 2 diabetic patients remains to be elucidated. An impaired mitochondrial function is a likely candidate.

\section{Adipose tissue}

GLUT4 expression is down-regulated in adipose tissue in patients with T2DM (Shepherd \& Kahn 1999). Given that skeletal muscle is the major site for glucose disposal, the hyperglycemia associated with T2DM cannot be explained by the decreased uptake of glucose into adipose tissue due to downregulation of GLUT4 in adipocytes. Furthermore, adipocyte-selective knockout of GLUT4 (adiposeGlut4-/-) in mice resulted in systemic insulin resistance similar to that induced by muscle-selective Glut 4 knockout mice (Zisman et al. 2000, Abel et al. 2001). These studies indicate that adipocyte GLUT4 deficiency may result in generation of circulating factors that are responsible for crossorgan communication. Retinol-binding protein-4 (RBP4) was recently identified as one candidate for that crosstalk in the adipose tissue of adipose-specific Glut 4 knockout mice (Yang et al. 2005). Furthermore, serum RBP4 protein levels were elevated in insulin-resistant mice and obese and diabetic humans. Transgenic overexpression of the human RBP4 gene or injection of recombinant RBP4 protein in normal mice caused insulin resistance, whereas RBP4 knockout mice had enhanced insulin sensitivity (Yang et al. 2005). Increased serum RBP4 protein levels induced hepatic expression of the gluconeogenic enzyme phosphoenolpyruvate carboxykinase and impaired insulin signaling in muscle. Adipocytes, both visceral and peripheral, secrete a plethora of factors, which may alter systemic insulin action and hepatic glucose production, including adiponectin, resistin, leptin, cytokines IL6 and TNF $\alpha$, visfatin, RBP4, as well as FFA (Gimeno \& Klaman 2005, Lazar 2005, Wellen \& Hotamisligil 2005). The inhibition of signaling downstream of the insulin receptor may be a primary mechanism through which this inflammatory state causes insulin resistance. Exposure of cells to TNF $\alpha$ or elevated levels of FFAs stimulates phosphorylation of serine residues of IRS1. This phosphorylation reduces tyrosine phosphorylation of IRS1 in response to insulin (Hotamisligil et al. 1996, Paz et al. 1997, Aguirre et al. 2000, 2002). Both adipose tissue and the macrophages within adipose tissue serve in both endocrine and paracrine fashions to promote inflammation and decrease insulin sensitivity (Wellen \& Hotamisligil 2005, de Luca \& Olefsky 2006).

\section{Pancreatic $\beta$-cells}

Many mechanisms contributing to T2DM may also trigger $\beta$-cell apoptosis and reduce $\beta$-cell mass or ability to compensate for insulin resistance (Rhodes 2005). Mechanisms include endoplasmic reticulum stress (Harding \& Ron 2002), chronic hyperglycemia (Donath \& Halban 2004), chronic hyperlipidemia (Poitout \& Robertson 2002), oxidative stress (Kaneto et al. 2006), and inflammatory cytokines (Donath et al. 2003). Decreased IRS2 expression 
may lead to spontaneous $\beta$-cell apoptosis (Hennige et al. 2003). Because several mechanisms relevant to pathogenesis of T2DM may increase IRS2 serine/threonine phosphorylation (Werner et al. 2004) with resultant IRS2 ubiquitination and proteosomal degradation, defects in insulin signaling and insulin secretion may be coupled. When $\beta$-cell function is viewed in the context of reduced insulin sensitivity, considerable data support the early failure of insulin secretion in T2DM pathogenesis (Ferrannini 1998, Kahn 2003). Animal studies also support this concept. However, the signals that cause normal $\beta$-cell compensation and hyperinsulinemia, the mechanisms of this compensation, the point in the pathogenesis of T2DM where this compensatory mechanism fails, and the etiology of this failure all remain unclear. Insulin sensitivity and insulin secretion are deteriorated in human T2DM.

\section{Liver}

Liver is the major organ with the ability to consume, store, and produce glucose and lipids. Hepatic glucose metabolism includes the formation of glycogen (short-term energy storage), generation of glucose from nonsugar carbon substrates and intracellular energy supply via glycolysis (Klover \& Mooney 2004). Fatty acid oxidation, de novo synthesis of fatty acids, cholesterol and bile acid synthesis, as well as lipoprotein assembly are the essential processes in lipid metabolism. These metabolic pathways are coordinately regulated to maintain glucose and lipid homeostasis under physiological conditions (Raddatz \& Ramadori 2007). Consequently, the liver is a key target for the anabolic hormone insulin and its catabolic counterpart glucagon. Insulin is released from the pancreatic $\beta$-cells in response to increased blood glucose concentrations, and this is amplified in the presence of FFAs. Impaired insulin sensitivity and dysregulated insulin action in the liver contributes significantly to the pathogenesis of T2DM (Fritsche et al. 2008). The pancreatic $\alpha$-cells release glucagon in response to decreasing blood glucose concentrations as it occurs during fasting. Glucagon affects mainly the liver and adipose tissue. It induces the breakdown of glycogen and the mobilization of fatty acids. Most importantly, it promotes gluconeogenesis, i.e. the formation of glucose from lactate, glycerol and glucogenic amino acids.

IRS -1 and -2 are complementary key players in the regulation of hepatic insulin signaling and expression of genes involved in gluconeogenesis, glycogen synthesis, and lipid metabolism (Fritsche et al. 2008). The function of IRS proteins is regulated by their expression levels and posttranslational modifications. Dysfunction of IRS proteins initially leads to postprandial hyperglycemia, increased hepatic glucose production, and dysregulated lipid synthesis, and is considered as a major pathophysiological mechanism for the development of insulin resistance and T2DM (Taniguchi et al. 2005, Dong et al. 2006, Simmgen et al. 2006). Irs 2 knockout mice have a progressive development of
T2DM, increased adiposity and female infertility (Withers 2001), with insulin resistance in the liver and skeletal muscle, together with a lack of $\beta$-cell compensation for the peripheral insulin resistance (Lin et al. 2004).

\section{Multiorgan disease}

Previously, resistance to insulin-mediated nonoxidative glucose metabolism was viewed as the early and primary defect leading to T2DM, and thereafter the progressive failure of the $\beta$-cell to compensate for insulin resistance has received considerable attention (Kahn 2003). Most recently, data from animal models have challenged this paradigm. Muscle-specific insulin receptor (IR or INSR as given in the HUGO Database) inactivation did not lead to impaired glucose tolerance (IGT) despite insulin resistance, whereas musclespecific inactivation of glucose transporter GLUT4 caused both profound insulin resistance and T2DM (Minokoshi et al. 2003). GLUT4 inactivation limited to white adipose tissue resulted in insulin resistance, glucose intolerance, and even T2DM with impairment in whole body glucose uptake markedly out of proportion to the expected contribution of white adipose tissue (Minokoshi et al. 2003). This isolated defect in white adipose tissue resulted in defective insulin action in both muscle and liver. These studies suggest a central and previously under-appreciated role of adipocytes in the pathogenesis of T2DM. However, insulin receptor inactivation in the liver also resulted in hyperinsulinemia, hepatic insulin resistance, and peripheral insulin resistance (Michael et al. 2000, Baudry et al. 2002, Mauvais-Jarvis et al. 2002, Fisher \& Kahn 2003). These studies suggest considerable crosstalk among organ systems, as well as an important role for insulin signaling pathways in the $\beta$-cell (Accili 2004).

The central nerve system (CNS) has been shown to have an essential role in regulating glucose metabolism by sensing and integrating information from neural, hormonal, and nutrient signals, and then modulating glucose output in the liver and glucose uptake in peripheral tissues (Sandoval et al. 2009). Data from animal experiments have been documented to show that overeating and obesity dampen the ability of the CNS to sense and respond to the information, whereas selective CNS interventions decrease insulin resistance and blood glucose levels (Sandoval et al. 2009).

Thus, T2DM is the final outcome of a multiorgan disease, which is characterized by early direct or indirect defects in muscle, adipocytes, hepatocytes, $\beta$-cells, and the CNS.

\section{Mitochondria and reactive oxygen species}

Reactive oxygen species (ROS) may regulate insulin resistance. Several lines of evidence support the association of oxidative stress markers with diabetes (Urakawa et al. 2003, Furukawa et al. 2004, Lin et al. 2005). Recent data showed that treatment of 3T3-L1 adipocyte with either $\mathrm{TNF} \alpha$ or dexamethasone increased the ROS level and resulted in decreased insulin action (Houstis et al. 2006). 
Antioxidant molecules or transgenes encoding ROSscavenging enzymes both ameliorated the insulin resistance of TNF $\alpha$ - or dexamethasone-treated 3T3-L1 adipocytes to varying degrees. Furthermore, antioxidant molecules improved insulin sensitivity and glucose homeostasis in ob/ ob mice (Houstis et al. 2006). Reduced mitochondrial oxidative phosphorylation has recently been demonstrated in human diabetes, using both microarrays to identify downregulated genes involved in oxidative phosphorylation (OXPHOS genes). PGC1 (PPARGC1A as given in the HUGO Database) appears to be at least partially responsible for this defect (Mootha et al. 2003, Patti et al. 2003). Supportive studies in humans have suggested a role for defective mitochondrial fatty acid oxidation, mitochondrial dysfunction, and reduced numbers of skeletal muscle mitochondria in T2DM pathogenesis, and have suggested that increased intramyocellular lipid content was associated with defects in mitochondrial activity (Maechler \& Wollheim 2001, Petersen et al. 2004, Lowell \& Shulman 2005, Morino et al. 2005). There is $38 \%$ less mitochondrial density in muscle of insulin resistant individuals compared with controls (Morino et al. 2005). The decreased mitochondrial fatty acid oxidation, caused by either mitochondrial dysfunction and/or reduced mitochondrial numbers, produces increased levels of intracellular fatty acyl CoA and diacylglycerol. These molecules activate a novel protein kinase $\mathrm{C}$, which in turn activates a serine kinase cascade, leading to increased serine phosphorylation of IRS1. As described above, serine phosphorylation blocks IRS1 tyrosine phosphorylation and inhibits downstream signaling, including recruitment of GLUT4 to the plasma membrane and insulin-mediated glucose uptake in skeletal muscle (Lowell \& Shulman 2005).

\section{Obesity and physical inactivity}

Only about one-third of adults in America are considered to have 'normal' weight, and similar trends are being observed worldwide (Kahn et al. 2006). About $80 \%$ of T2DM is associated with obesity and sedentary life styles (Venables \& Jeukendrup 2009). It is well accepted that obesity and physical inactivity are risk factors for the development of T2DM (Weinstein et al. 2004).

In obesity, the disparity between uptake of fatty acids into skeletal muscle and oxidation results in excessive accumulation of triacylglycerol and fatty acid metabolites such as long-chain acyl-CoAs, diacylglycerols, and ceramides in the sarcoplasm of skeletal muscle (Venables \& Jeukendrup 2009). It has been reported that an elevation in circulating fatty acids was associated with a decrease in insulin signaling and glucose disposal rates (Belfort et al. 2005). An increase in skeletal muscle diacylglycerol content in human and animal models of insulin resistance activates specific isoforms of protein kinase $\mathrm{C}$, leading to inhibition of the insulin signal through serine phosphorylation of IRS1 (Itani et al. 2002, Yu et al. 2002). For obesity and insulin resistance to be associated with type 2 diabetes, $\beta$-cells must be unable to compensate fully for decreased insulin sensitivity (Kahn et al. 2006). Dysfunction of $\beta$-cells exists in individuals who are at high risk of developing T2DM even when their glucose levels are still normal, suggesting that $\beta$-cell dysfunction could be crucial (Kahn et al. 2006).

Many prospective studies have shown strong association between daily physical activity and a reduced risk of developing T2DM (Venables \& Jeukendrup 2009). Clinical trials have also shown that addition of physical activity and dietary modification can reduce the incidence of T2DM (Venables \& Jeukendrup 2009). Recent data have indicated that elevations in mitochondrial oxidative capacity following an acute bout of exercise can increase insulin-stimulated glucose uptake (Thyfault et al. 2007).

\section{Genetic analysis}

The genetic information in the family history has been used in clinical assessment of T2DM (Majithia \& Florez 2009). There is ample evidence that T2DM has a strong genetic component, which includes monogenic disease such as MODY1-6 (described to date) under 25 years of age and polygenic disease such as common T2DM (Majithia \& Florez 2009). The lifetime risk of T2DM is about $7 \%$ in a general population, about $40 \%$ in offspring of one parent with T2DM, and about $70 \%$ if both parents have diabetes (Majithia \& Florez 2009). The first-degree family with a history of T2DM is associated with twofold increased risk of future T2DM (Lyssenko et al. 2008).

Genetic studies including linkage analysis, candidate gene approaches, and most recent genome-wide association studies have identified 20 common genetic variants associated with T2DM (Ridderstrale \& Groop 2009). Many loci appear to regulate the capacity of $\beta$-cells to increase insulin secretion in response to an increase in insulin resistance or obesity, which includes eight genes such as TCF7L2, KCNJ11, HHEX, SLC30A8, CDKAL1, CDKN2A/2B, IGF2BP2, and KCNQ; PPARG gene is related to insulin sensitivity; $C A P N 10$ gene is related to glucose transport; $M C 4 R$ and FTO genes are related to obesity; eight other loci have unknown roles in T2DM (Ridderstrale \& Groop 2009).

\section{Animal models of T2DM}

Animal models of T2DM are excellent tools to study the pathogenesis of human disease. Owing to the uncertain etiology of T2DM and its causes are multifarious, the use of various animal models, each of which induces the disease by a different mechanism yet with the same end result, is advantageous. Animal models of T2DM include a wide range of species with genetic, experimental, or nutritional causation (Table 1; Srinivasan \& Ramarao 2007). 

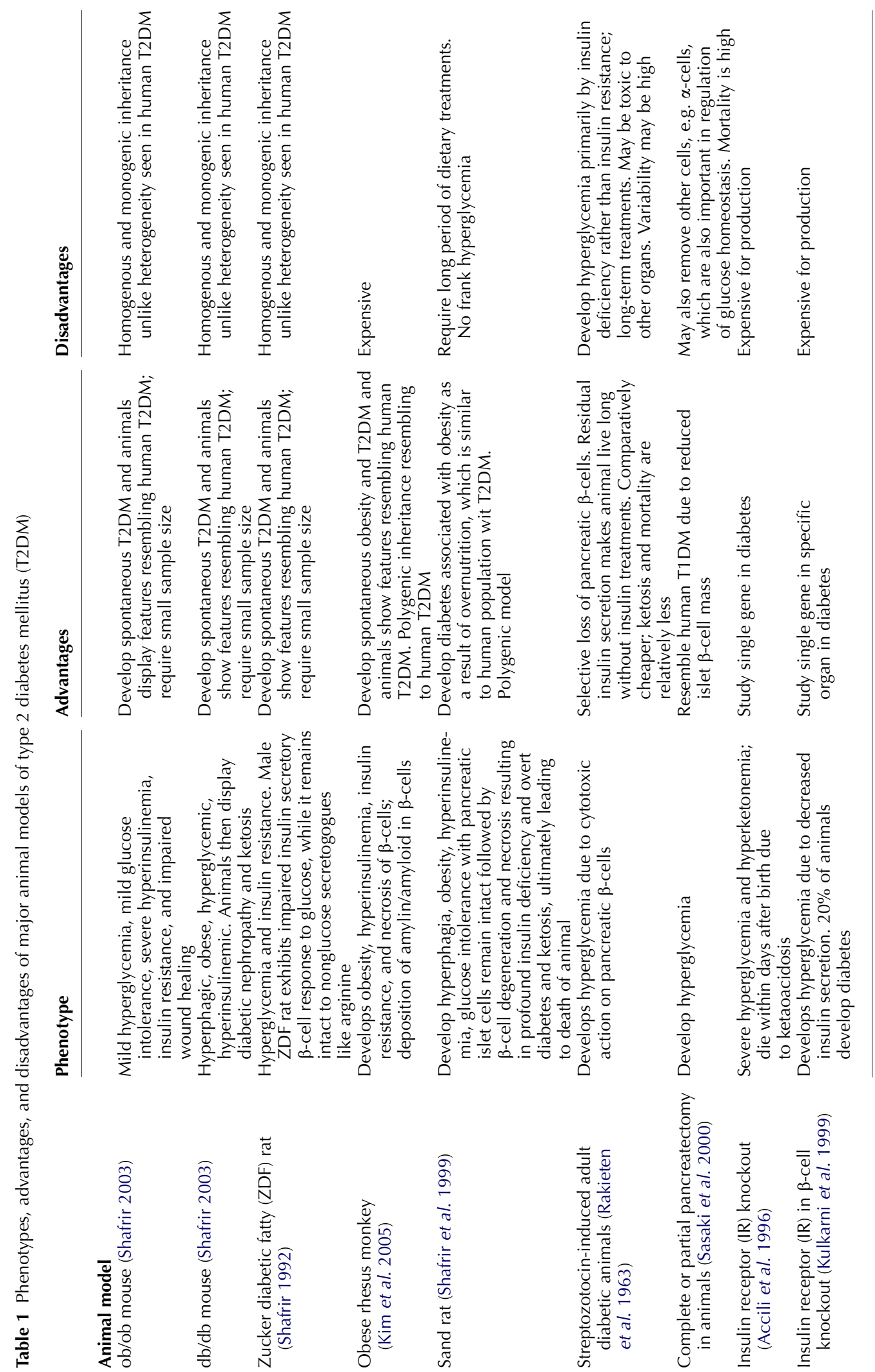


\section{Commonly used animal models of T2DM}

ob/ob mouse ob/ob mouse is inherited as autosomal recessive mutation on chromosome 6 in C57BL/6J mouse strain (Shafrir 2003). The mutation is in leptin gene, which encodes leptin protein. $\mathrm{Ob} / \mathrm{ob}$ mice are hyperphagic and obese. $\mathrm{Ob} / \mathrm{ob}$ mice display diabetes like syndrome of mild hyperglycemia, mild IGT, severe hyperinsulinemia, insulin resistance, and impaired wound healing. However, when ob gene is expressed on C57BL/KS background, mice become severely diabetic with regression of islets (Bell \& Hye 1983).

$\mathbf{d b} / \mathbf{d b}$ mouse $T$ he $\mathrm{db} / \mathrm{db}$ (diabetic) mouse is originally derived from an autosomal recessive mutation on chromosome 4 in mice of C57BL/KSJ strain (Shafrir 2003). The mutation is in $\mathrm{db}$ gene, which encodes for leptin receptors. $\mathrm{Db} / \mathrm{db}$ mice mimic several features of human T2DM. These mice are spontaneously hyperphagic and obese. These mice show insulin resistance within the first month of age and develop hyperinsulinemia and hyperglycemia later with a peak between 3 and 4 months of age. Animals then display diabetic nephropathy and ketosis, which are similar to advanced human T2DM (Shafrir 2003, Sharma et al. 2003).

Zucker fatty rat The spontaneous mutation obese (fatty) model was found in the rat stock of Sherman and Merck by Zucker in 1961. The Zucker (fa/fa) fatty or obese rat results from the simple autosomal recessive $(\mathrm{fa})$ gene on chromosome 5 , which encodes leptin receptors. It has hyperphagia and early onset of obesity, which appear at 4 weeks of age along with increased growth of subcutaneous fat depot, which mimics the early stage of human T2DM. It shows mild hyperglycemia, insulin resistance, mild glucose intolerance, hyperlipidemia, hyperinsulinemia, and moderate hypertension (Durham \& Truett 2006).

Zucker diabetic fatty rat It is a substrain of Zucker fatty rat selectively inbred for hyperglycemia. Male Zucker diabetic fatty rat progresses to diabetes due to failure to compensate adequately for insulin resistance (Shafrir 1992). In contrast to $\mathrm{fa} / \mathrm{fa}$ rats, the ability to over secrete insulin to compensate peripheral insulin resistance is limited, and the $\beta$-cells are brittle and easily succumb to over secretion pressure. It exhibits impaired insulin secretory $\beta$-cell response to glucose, while it remains intact to nonglucose secretogogues like arginine, a phenomenon similar to human T2DM.

Obese rhesus monkey (Macaca mullata) Obese rhesus monkey develops obesity, hyperinsulinemia, and insulin resistance when maintained on ad libitum laboratory diet, which gradually progresses to necrosis of $\beta$-cells, severe fall in insulin levels and overt hyperglycemia over a period of several years (Kim et al. 2005). The most remarkable similarity may be the prediabetic phase with insulin resistance and compensatory hyperinsulinemia, which is well documented in the human condition. The final loss of insulin secretion is interestingly associated with the deposition of amylin/amyloid in $\beta$-cells (Ramarao \& Kaul 1999, Kim et al. 2005). Islet amyloid is found in about $90 \%$ of human T2DM (Cefalu 2006).

These obese animal models have provided unique tools for studying how obesity causes T2DM. For example, $d b / d b$ mice were generated by mutation of the leptin receptor gene. Owing to genetic deficiency of leptin receptors, $\mathrm{db} / \mathrm{db}$ mice are hyperphagic and therefore obese. These animals develop severe hyperglycemia, insulin resistance, and $\beta$-cell dysfunction. These characteristics mimic those of human T2DM. Indeed, each animal model was developed to mimic certain aspects of human T2DM. In addition, animal models of T2DM are essential tools for testing new anti-diabetic drugs.

The characteristics, advantages, and disadvantages of the major T2DM models are provided in Table 1.

\section{Summary}

T2DM is a complex heterogeneous group of metabolic disorders characterized by hyperglycemia and impaired insulin action and/or insulin secretion. The complex nature of T2DM reflects the multifaceted genetic background and the varied genetic-environmental interaction. The current theories of T2DM include a defect in insulin-mediated glucose uptake, a dysfunction of the pancreatic $\beta$-cell, a dysregulation of the adipocyte as a secretory organ, and a dysfunction of the liver. Dysregulation of metabolism in diabetes also causes extensive complications in nearly all organs or tissues. Recent advances in animal models of T2DM make it possible to explore the previously unidentified pathogenesis of the disease.

\section{Declaration of interest}

There is no conflict of interest that could be perceived as prejudicing the impartiality of the research reported.

\section{Funding}

This work was supported by the National Institute of Health (HL077490 to $\mathrm{ZS}$ ).

\section{References}

Abel ED, Peroni O, Kim JK, Kim YB, Boss O, Hadro E, Minnemann T, Shulman GI \& Kahn BB 2001 Adipose-selective targeting of the GLUT4 gene impairs insulin action in muscle and liver. Nature 409 729-733.

Accili D 2004 Lilly lecture 2003: the struggle for mastery in insulin action: from triumvirate to republic. Diabetes $\mathbf{5 3} 1633-1642$.

Accili D, Drago J, Lee EJ, Johnson MD, Cool MH, Salvatore P, Asico LD, Jose PA, Taylor SI \& Westphal H 1996 Early neonatal death in mice homozygous for a null allele of the insulin receptor gene. Nature Genetics 12 106-109. 
Aguirre V, Uchida T, Yenush L, Davis R \& White MF 2000 The c-Jun $\mathrm{NH}(2)$-terminal kinase promotes insulin resistance during association with insulin receptor substrate-1 and phosphorylation of Ser(307). Journal of Biological Chemistry 275 9047-9054.

Aguirre V, Werner ED, Giraud J, Lee YH, Shoelson SE \& White MF 2002 Phosphorylation of Ser307 in insulin receptor substrate-1 blocks interactions with the insulin receptor and inhibits insulin action. Journal of Biological Chemistry 277 1531-1537.

Ahmad F, Azevedo JL, Cortright R, Dohm GL \& Goldstein BJ 1997 Alterations in skeletal muscle protein-tyrosine phosphatase activity and expression in insulin-resistant human obesity and diabetes. Journal of Clinical Investigation 100 449-458.

Araki E, Lipes MA, Patti ME, Bruning JC, Haag B III, Johnson RS \& Kahn CR 1994 Alternative pathway of insulin signalling in mice with targeted disruption of the IRS-1 gene. Nature 372 186-190.

Asano T, Fujishiro M, Kushiyama A, Nakatsu Y, Yoneda M, Kamata H \& Sakoda H 2007 Role of phosphatidylinositol 3-kinase activation on insulin action and its alteration in diabetic conditions. Biological \& Pharmacentical Bulletin 30 1610-1616.

Bandyopadhyay D, Kusari A, Kenner KA, Liu F, Chernoff J, Gustafson TA \& Kusari J 1997a Protein-tyrosine phosphatase 1B complexes with the insulin receptor in vivo and is tyrosine-phosphorylated in the presence of insulin. Journal of Biological Chemistry 272 1639-1645.

Bandyopadhyay G, Standaert ML, Galloway L, Moscat J \& Farese RV 1997 b Evidence for involvement of protein kinase $\mathrm{C}$ (PKC)-zeta and noninvolvement of diacylglycerol-sensitive PKCs in insulin-stimulated glucose transport in L6 myotubes. Endocrinology 138 4721-4731.

Baudry A, Leroux L, Jackerott M \& Joshi RL 2002 Genetic manipulation of insulin signaling, action and secretion in mice. Insights into glucose homeostasis and pathogenesis of type 2 diabetes. EMBO Reports 3 323-328.

Belfort R, Mandarino L, Kashyap S, Wirfel K, Pratipanawatr T, Berria R, Defronzo RA \& Cusi K 2005 Dose-response effect of elevated plasma free fatty acid on insulin signaling. Diabetes 54 1640-1648.

Bell RH Jr \& Hye RJ 1983 Animal models of diabetes mellitus: physiology and pathology. Journal of Surgical Research 35 433-460.

Bjornholm M \& Zierath JR 2005 Insulin signal transduction in human skeletal muscle: identifying the defects in type II diabetes. Biochemical Society Transactions 33 354-357.

Blaak EE, van Aggel-Leijssen DP, Wagenmakers AJ, Saris WH \& van Baak MA 2000a Impaired oxidation of plasma-derived fatty acids in type 2 diabetic subjects during moderate-intensity exercise. Diabetes $\mathbf{4 9}$ 2102-2107.

Blaak EE, Wagenmakers AJ, Glatz JF, Wolffenbuttel BH, Kemerink GJ, Langenberg CJ, Heidendal GA \& Saris WH 2000b Plasma FFA utilization and fatty acid-binding protein content are diminished in type 2 diabetic muscle. American Journal of Physiology. Endocrinology and Metabolism 279 E146-E154.

Boden G 1999 Free fatty acids, insulin resistance, and type 2 diabetes mellitus. Proceedings of the Association of American Physicians 111 241-248.

Cefalu WT 2006 Animal models of type 2 diabetes: clinical presentation and pathophysiological relevance to the human condition. ILAR Journal/National Research Council, Institute of Laboratory Animal Resources 47 186-198.

Das SK \& Elbein SC 2006 The genetic basis of type 2 diabetes. Cellscience 2 100-131.

DeFronzo RA, Bonadonna RC \& Ferrannini E 1992 Pathogenesis of NIDDM. A balanced overview. Diabetes Care 15 318-368.

Donath MY \& Halban PA 2004 Decreased beta-cell mass in diabetes: significance, mechanisms and therapeutic implications. Diabetologia $\mathbf{4 7}$ 581-589.

Donath MY, Storling J, Maedler K \& Mandrup-Poulsen T 2003 Inflammatory mediators and islet beta-cell failure: a link between type 1 and type 2 diabetes. Journal of Molecular Medicine 81 455-470.

Dong X, Park S, Lin X, Copps K, Yi X \& White MF 2006 Irs1 and Irs2 signaling is essential for hepatic glucose homeostasis and systemic growth. Journal of Clinical Investigation 116 101-114.
Durham HA \& Truett GE 2006 Development of insulin resistance and hyperphagia in Zucker fatty rats. American Journal of Physiology. Regulatory, Integrative and Comparative Physiology 290 R652-R658.

Elchebly M, Payette P, Michaliszyn E, Cromlish W, Collins S, Loy AL, Normandin D, Cheng A, Himms-Hagen J, Chan CC et al. 1999 Increased insulin sensitivity and obesity resistance in mice lacking the protein tyrosine phosphatase-1B gene. Science 283 1544-1548.

De Fea K \& Roth RA 1997 Protein kinase C modulation of insulin receptor substrate-1 tyrosine phosphorylation requires serine 612. Biochemistry 36 12939-12947.

Ferrannini E 1998 Insulin resistance versus insulin deficiency in non-insulindependent diabetes mellitus: problems and prospects. Endocrine Reviews 19 $477-490$.

Fisher SJ \& Kahn CR 2003 Insulin signaling is required for insulin's direct and indirect action on hepatic glucose production. Journal of Clinical Investigation $111463-468$.

Foster LJ \& Klip A 2000 Mechanism and regulation of GLUT-4 vesicle fusion in muscle and fat cells. American Journal of Physiology. Cell Physiology 279 C877-C890.

Fritsche L, Weigert C, Haring HU \& Lehmann R 2008 How insulin receptor substrate proteins regulate the metabolic capacity of the liver - implications for health and disease. Current Medicinal Chemistry 15 1316-1329.

Frittitta L, Youngren JF, Sbraccia P, D'Adamo M, Buongiorno A, Vigneri R, Goldfine ID \& Trischitta V 1997 Increased adipose tissue PC-1 protein content, but not tumour necrosis factor-alpha gene expression, is associated with a reduction of both whole body insulin sensitivity and insulin receptor tyrosine-kinase activity. Diabetologia 40 282-289.

Furukawa S, Fujita T, Shimabukuro M, Iwaki M, Yamada Y, Nakajima Y, Nakayama O, Makishima M, Matsuda M \& Shimomura I 2004 Increased oxidative stress in obesity and its impact on metabolic syndrome. Journal of Clinical Investigation 114 1752-1761.

Gimeno RE \& Klaman LD 2005 Adipose tissue as an active endocrine organ: recent advances. Current Opinion in Pharmacology 5 122-128.

Harding HP \& Ron D 2002 Endoplasmic reticulum stress and the development of diabetes: a review. Diabetes 51 S455-S461.

Hennige AM, Burks DJ, Ozcan U, Kulkarni RN, Ye J, Park S, Schubert M, Fisher TL, Dow MA, Leshan R et al. 2003 Upregulation of insulin receptor substrate-2 in pancreatic beta cells prevents diabetes. Journal of Clinical Investigation 112 1521-1532.

Hotamisligil GS, Shargill NS \& Spiegelman BM 1993 Adipose expression of tumor necrosis factor-alpha: direct role in obesity-linked insulin resistance. Science 259 87-91.

Hotamisligil GS, Peraldi P, Budavari A, Ellis R, White MF \& Spiegelman BM 1996 IRS-1-mediated inhibition of insulin receptor tyrosine kinase activity in TNF-alpha- and obesity-induced insulin resistance. Science 271 665-668.

Houstis N, Rosen ED \& Lander ES 2006 Reactive oxygen species have a causal role in multiple forms of insulin resistance. Nature 440 944-948.

Hubbard SR, Wei L, Ellis L \& Hendrickson WA 1994 Crystal structure of the tyrosine kinase domain of the human insulin receptor. Nature $\mathbf{3 7 2}$ 746-754.

Itani SI, Ruderman NB, Schmieder F \& Boden G 2002 Lipid-induced insulin resistance in human muscle is associated with changes in diacylglycerol, protein kinase C, and IkappaB-alpha. Diabetes 51 2005-2011.

Jahn R \& Scheller RH 2006 SNAREs - engines for membrane fusion. Nature Reviews. Molecular Cell Biology 7 631-643.

Joost HG, Bell GI, Best JD, Birnbaum MJ, Charron MJ, Chen YT, Doege H, James DE, Lodish HF, Moley KH et al. 2002 Nomenclature of the GLUT/SLC2A family of sugar/polyol transport facilitators. American Journal of Physiology. Endocrinology and Metabolism 282 E974-E976.

Kahn SE 2003 The relative contributions of insulin resistance and beta-cell dysfunction to the pathophysiology of type 2 diabetes. Diabetologia 46 3-19.

Kahn SE, Hull RL \& Utzschneider KM 2006 Mechanisms linking obesity to insulin resistance and type 2 diabetes. Nature 444 840-846.

Kanda H, Tamori Y, Shinoda H, Yoshikawa M, Sakaue M, Udagawa J, Otani H, Tashiro F, Miyazaki J \& Kasuga M 2005 Adipocytes from Munc18c-null mice show increased sensitivity to insulin-stimulated GLUT4 externalization. Journal of Clinical Investigation 115 291-301. 
Kaneto H, Nakatani Y, Kawamori D, Miyatsuka T, Matsuoka TA, Matsuhisa M \& Yamasaki Y 2006 Role of oxidative stress, endoplasmic reticulum stress, and c-Jun $\mathrm{N}$-terminal kinase in pancreatic beta-cell dysfunction and insulin resistance. International Journal of Biochemistry and Cell Biology 38 782-793.

Kawanishi M, Tamori Y, Okazawa H, Araki S, Shinoda H \& Kasuga M 2000 Role of SNAP23 in insulin-induced translocation of GLUT4 in 3T3-L1 adipocytes. Mediation of complex formation between syntaxin 4 and VAMP2. Journal of Biological Chemistry 275 8240-8247.

Kelley DE \& Mandarino LJ 2000 Fuel selection in human skeletal muscle in insulin resistance: a reexamination. Diabetes 49 677-683.

Kelley DE \& Simoneau JA 1994 Impaired free fatty acid utilization by skeletal muscle in non-insulin-dependent diabetes mellitus. Journal of Clinical Investigation 94 2349-2356.

Kim SY, Johnson MA, McLeod DS, Alexander T, Hansen BC \& Lutty GA 2005 Neutrophils are associated with capillary closure in spontaneously diabetic monkey retinas. Diabetes 54 1534-1542.

Klover PJ \& Mooney RA 2004 Hepatocytes: critical for glucose homeostasis. International Journal of Biochemistry \& Cell Biology 36 753-758.

Kulkarni RN, Bruning JC, Winnay JN, Postic C, Magnuson MA \& Kahn CR 1999 Tissue-specific knockout of the insulin receptor in pancreatic beta cells creates an insulin secretory defect similar to that in type 2 diabetes. Cell 96 329-339.

Latham CF, Lopez JA, Hu SH, Gee CL, Westbury E, Blair DH, Armishaw CJ, Alewood PF, Bryant NJ, James DE et al. 2006 Molecular dissection of the Munc18c/syntaxin 4 interaction: implications for regulation of membrane trafficking. Traffic 7 1408-1419.

Lazar MA 2005 How obesity causes diabetes: not a tall tale. Science 307 373-375.

Lin X, Taguchi A, Park S, Kushner JA, Li F, Li Y \& White MF 2004 Dysregulation of insulin receptor substrate 2 in beta cells and brain causes obesity and diabetes. Journal of Clinical Investigation 114 908-916.

Lin Y, Berg AH, Iyengar P, Lam TK, Giacca A, Combs TP, Rajala MW, Du X, Rollman B, Li W et al. 2005 The hyperglycemia-induced inflammatory response in adipocytes: the role of reactive oxygen species. Journal of Biological Chemistry 280 4617-4626.

Louvi A, Accili D \& Efstratiadis A 1997 Growth-promoting interaction of IGF-II with the insulin receptor during mouse embryonic development. Developmental Biology 189 33-48.

Lowell BB \& Shulman GI 2005 Mitochondrial dysfunction and type 2 diabetes. Science 307 384-387.

de Luca C \& Olefsky JM 2006 Stressed out about obesity and insulin resistance. Nature Medicine 12 41-42.

Lyssenko V, Jonsson A, Almgren P, Pulizzi N, Isomaa B, Tuomi T, Berglund G, Altshuler D, Nilsson P \& Groop L 2008 Clinical risk factors, DNA variants, and the development of type 2 diabetes. New England Journal of Medicine 359 2220-2232.

Maechler P \& Wollheim CB 2001 Mitochondrial function in normal and diabetic beta-cells. Nature 414 807-812.

Majithia AR \& Florez JC 2009 Clinical translation of genetic predictors for type 2 diabetes. Current Opinion in Endocrinology, Diabetes and Obesity 16 $100-106$.

Mastick CC \& Falick AL 1997 Association of N-ethylmaleimide sensitive fusion (NSF) protein and soluble NSF attachment proteins-alpha and -gamma with glucose transporter-4-containing vesicles in primary rat adipocytes. Endocrinology 138 2391-2397.

Mauvais-Jarvis F, Kulkarni RN \& Kahn CR 2002 Knockout models are useful tools to dissect the pathophysiology and genetics of insulin resistance. Clinical Endocrinology 57 1-9.

McKern NM, Lawrence MC, Streltsov VA, Lou MZ, Adams TE, Lovrecz GO, Elleman TC, Richards KM, Bentley JD, Pilling PA et al. 2006 Structure of the insulin receptor ectodomain reveals a folded-over conformation. Nature 443 218-221.

McNew JA, Parlati F, Fukuda R, Johnston RJ, Paz K, Paumet F, Sollner TH \& Rothman JE 2000 Compartmental specificity of cellular membrane fusion encoded in SNARE proteins. Nature 407 153-159.

Michael MD, Kulkarni RN, Postic C, Previs SF, Shulman GI, Magnuson MA \& Kahn CR 2000 Loss of insulin signaling in hepatocytes leads to severe insulin resistance and progressive hepatic dysfunction. Molecular Cell 6 87-97.
Minokoshi Y, Kahn CR \& Kahn BB 2003 Tissue-specific ablation of the GLUT4 glucose transporter or the insulin receptor challenges assumptions about insulin action and glucose homeostasis. Journal of Biological Chemistry 278 33609-33612.

Moller DE 2000 Potential role of TNF-alpha in the pathogenesis of insulin resistance and type 2 diabetes. Trends in Endocrinology and Metabolism $11212-217$

Mootha VK, Lindgren CM, Eriksson KF, Subramanian A, Sihag S, Lehar J, Puigserver P, Carlsson E, Ridderstrale M, Laurila E et al. 2003 PGC-1alpha-responsive genes involved in oxidative phosphorylation are coordinately downregulated in human diabetes. Nature Genetics 34 $267-273$.

Morino K, Petersen KF, Dufour S, Befroy D, Frattini J, Shatzkes N, Neschen S, White MF, Bilz S, Sono S et al. 2005 Reduced mitochondrial density and increased IRS-1 serine phosphorylation in muscle of insulinresistant offspring of type 2 diabetic parents. Journal of Clinical Investigation 115 3587-3593.

Patti ME, Butte AJ, Crunkhorn S, Cusi K, Berria R, Kashyap S, Miyazaki Y, Kohane I, Costello M, Saccone R et al. 2003 Coordinated reduction of genes of oxidative metabolism in humans with insulin resistance and diabetes: potential role of PGC1 and NRF1. PNAS 100 8466-8471.

Paz K, Hemi R, LeRoith D, Karasik A, Elhanany E, Kanety H \& Zick Y 1997 A molecular basis for insulin resistance. Elevated serine/threonine phosphorylation of IRS-1 and IRS-2 inhibits their binding to the juxtamembrane region of the insulin receptor and impairs their ability to undergo insulin-induced tyrosine phosphorylation. Journal of Biological Chemistry 272 29911-29918.

Petersen KF, Dufour S, Befroy D, Garcia R \& Shulman GI 2004 Impaired mitochondrial activity in the insulin-resistant offspring of patients with type 2 diabetes. New England Journal of Medicine 350 664-671.

Poitout V \& Robertson RP 2002 Minireview: secondary beta-cell failure in type 2 diabetes - a convergence of glucotoxicity and lipotoxicity. Endocrinology 143 339-342.

Raddatz D \& Ramadori G 2007 Carbohydrate metabolism and the liver: actual aspects from physiology and disease. Zeitschrift für Gastroenterologie $\mathbf{4 5}$ $51-62$.

Rakieten N, Rakieten ML \& Nadkarni MV 1963 Studies on the diabetogenic action of streptozotocin (NSC-37917). Cancer Chemotherapy Reports 29 91-98.

Ramarao P \& Kaul CL 1999 Insulin resistance: current therapeutic approaches. Drugs of Today 35 895-911.

Ren JM, Marshall BA, Gulve EA, Gao J, Johnson DW, Holloszy JO \& Mueckler M 1993 Evidence from transgenic mice that glucose transport is rate-limiting for glycogen deposition and glycolysis in skeletal muscle. Journal of Biological Chemistry 268 16113-16115.

Rhodes CJ 2005 Type 2 diabetes - a matter of beta-cell life and death? Science 307 380-384.

Ridderstrale M \& Groop L 2009 Genetic dissection of type 2 diabetes. Molecular and Cellular Endocrinology 297 10-17.

Sandoval DA, Obici S \& Seeley RJ 2009 Targeting the CNS to treat type 2 diabetes. Nature Reviews. Drug Discovery 8 386-398.

Santomauro AT, Boden G, Silva ME, Rocha DM, Santos RF, Ursich MJ, Strassmann PG \& Wajchenberg BL 1999 Overnight lowering of free fatty acids with Acipimox improves insulin resistance and glucose tolerance in obese diabetic and nondiabetic subjects. Diabetes 48 1836-1841.

Sasaki S, Nio Y, Hirahara N, Sato Y, Inoue Y, Iguchi C, Yamasawa K \& Tamura K 2000 Intraperitoneally implanted artificial pancrease with transkaryotic beta-cells on microcarrier beads in a diffusion chamber improves hyperglycemia after $90 \%$ pancreatectomy in rats. In Vivo 14 535-541.

Schlessinger J 2000 Cell signaling by receptor tyrosine kinases. Cell 103 211-225.

Sciacca L, Prisco M, Wu A, Belfiore A, Vigneri R \& Baserga R 2003 Signaling differences from the A and B isoforms of the insulin receptor (IR) in 32D cells in the presence or absence of IR substrate-1. Endocrinology 144 2650-2658.

Shafrir E 1992 Animal models of non-insulin-dependent diabetes. Diabetes/Metabolism Reviews 8 179-208. 
Shafrir E 2003 Diabetes in animals: contribution to the understanding of diabetes by study of its etiopathology in animal models. In Diabetes Mellitus, pp 231-255. Eds D Porte, RS Sherwin \& A Baron. New York: McGraw-Hill.

Shafrir E, Ziv E \& Mosthaf L 1999 Nutritionally induced insulin resistance and receptor defect leading to beta-cell failure in animal models. Annals of the New York Academy of Sciences 892 223-246.

Sharma K, McCue P \& Dunn SR 2003 Diabetic kidney disease in the $\mathrm{db} / \mathrm{db}$ mouse. American Journal of Physiology. Renal Physiology 284 F1138-F1144.

Shepherd PR \& Kahn BB 1999 Glucose transporters and insulin action implications for insulin resistance and diabetes mellitus. New England Journal of Medicine 341 248-257.

Simmgen M, Knauf C, Lopez M, Choudhury AI, Charalambous M, Cantley J, Bedford DC, Claret M, Iglesias MA, Heffron $\mathrm{H}$ et al. 2006 Liver-specific deletion of insulin receptor substrate 2 does not impair hepatic glucose and lipid metabolism in mice. Diabetologia 49 552-561.

Smithers NP, Hodgkinson CP, Cuttle M \& Sale GJ 2008 Insulin-triggered repositioning of munc18c on syntaxin-4 in GLUT4 signalling. Biochemical Journal 410 255-260.

Srinivasan K \& Ramarao P 2007 Animal models in type 2 diabetes research: an overview. Indian Journal of Medical Research 125 451-472.

Stumvoll M, Goldstein BJ \& van Haeften TW 2005 Type 2 diabetes: principles of pathogenesis and therapy. Lancet 365 1333-1346.

Sun XJ, Wang LM, Zhang Y, Yenush L, Myers MG Jr, Glasheen E, Lane WS, Pierce JH \& White MF 1995 Role of IRS-2 in insulin and cytokine signalling. Nature 377 173-177.

Taguchi A \& White MF 2008 Insulin-like signaling, nutrient homeostasis, and life span. Annual Review of Physiology 70 191-212.

Taniguchi CM, Ueki K \& Kahn R 2005 Complementary roles of IRS-1 and IRS-2 in the hepatic regulation of metabolism. Indian Journal of Medical Research 115 718-727.

Thurmond DC, Ceresa BP, Okada S, Elmendorf JS, Coker K \& Pessin JE 1998 Regulation of insulin-stimulated GLUT4 translocation by Munc18c in 3T3L1 adipocytes. Journal of Biological Chemistry 273 33876-33883.

Thyfault JP, Cree MG, Zheng D, Zwetsloot JJ, Tapscott EB, Koves TR, Ilkayeva O, Wolfe RR, Muoio DM \& Dohm GL 2007 Contraction of insulin-resistant muscle normalizes insulin action in association with increased mitochondrial activity and fatty acid catabolism. American Journal of Physiology. Cell Physiology 292 C729-C739.

Tierney LM 2002 Current Medical Diagnosis and Treatment, 2002. New York: Lange Medical Books/McGraw-Hill.

Tordjman KM, Leingang KA, James DE \& Mueckler MM 1989 Differential regulation of two distinct glucose transporter species expressed in 3T3-L1 adipocytes: effect of chronic insulin and tolbutamide treatment. PNAS $\mathbf{8 6}$ 7761-7765.

Urakawa H, Katsuki A, Sumida Y, Gabazza EC, Murashima S, Morioka K, Maruyama N, Kitagawa N, Tanaka T, Hori Y et al. 2003 Oxidative stress is associated with adiposity and insulin resistance in men. Journal of Clinical Endocrinology and Metabolism 88 4673-4676.

Venables MC \& Jeukendrup AE 2009 Physical inactivity and obesity: links with insulin resistance and type 2 diabetes mellitus. International Journal of Experimental Diabetes Research 25 S18-S23.
Ward CW, Lawrence MC, Streltsov VA, Adams TE \& McKern NM 2007 The insulin and EGF receptor structures: new insights into ligand-induced receptor activation. Trends in Biochemical Sciences 32 129-137.

Weinstein AR, Sesso HD, Lee IM, Cook NR, Manson JE, Buring JE \& Gaziano JM 2004 Relationship of physical activity vs body mass index with type 2 diabetes in women. Journal of the American Medical Association 292 $1188-1194$.

Wellen KE \& Hotamisligil GS 2005 Inflammation, stress, and diabetes. Journal of Clinical Investigation 115 1111-1119.

Werner ED, Lee J, Hansen L, Yuan M \& Shoelson SE 2004 Insulin resistance due to phosphorylation of insulin receptor substrate-1 at serine 302 . Journal of Biological Chemistry 279 35298-35305.

White MF 2003 Insulin signaling in health and disease. Science 302 1710-1711.

White MF \& Kahn CR 1994 The insulin signaling system. Journal of Biological Chemistry 269 1-4.

Withers DJ 2001 Insulin receptor substrate proteins and neuroendocrine function. Biochemical Society Transactions 29 525-529.

Worm D, Vinten J, Staehr P, Henriksen JE, Handberg A \& Beck-Nielsen H 1996 Altered basal and insulin-stimulated phosphotyrosine phosphatase (PTPase) activity in skeletal muscle from NIDDM patients compared with control subjects. Diabetologia 39 1208-1214.

Yang Q, Graham TE, Mody N, Preitner F, Peroni OD, Zabolotny JM, Kotani K, Quadro L \& Kahn BB 2005 Serum retinol binding protein 4 contributes to insulin resistance in obesity and type 2 diabetes. Nature 436 356-362.

Yu C, Chen Y, Cline GW, Zhang D, Zong H, Wang Y, Bergeron R, Kim JK, Cushman SW, Cooney GJ et al. 2002 Mechanism by which fatty acids inhibit insulin activation of insulin receptor substrate-1 (IRS-1)-associated phosphatidylinositol 3-kinase activity in muscle. Journal of Biological Chemistry 277 50230-50236.

Zaid H, Antonescu CN, Randhawa VK \& Klip A 2008 Insulin action on glucose transporters through molecular switches, tracks and tethers. Biochemical Journal 413 201-215.

Zhande R, Mitchell JJ, Wu J \& Sun XJ 2002 Molecular mechanism of insulin-induced degradation of insulin receptor substrate 1. Molecular and Cellular Biology 22 1016-1026.

Zierath JR, Krook A \& Wallberg-Henriksson H 2000 Insulin action and insulin resistance in human skeletal muscle. Diabetologia 43 821-835.

Zimmet P, Alberti KG \& Shaw J 2001 Global and societal implications of the diabetes epidemic. Nature 414 782-787.

Zisman A, Peroni OD, Abel ED, Michael MD, Mauvais-Jarvis F, Lowell BB, Wojtaszewski JF, Hirshman MF, Virkamaki A, Goodyear LJ et al. 2000 Targeted disruption of the glucose transporter 4 selectively in muscle causes insulin resistance and glucose intolerance. Nature Medicine 6 924-928.

Received in final form 28 August 2009

Accepted 18 September 2009

Made available online as an Accepted Preprint

18 September 2009 